\title{
Revista Vernáculo 15 anos, um editorial
}

\author{
Alysson de Avila Costa ${ }^{1}$ \\ Francielle de Souza ${ }^{2}$ \\ Hilton Costa ${ }^{3}$
}

O presente número da Revista Vernáculo marca algo deveras impressionante: os 15 anos deste periódico! Uma das primeiras revistas voltadas para discentes de graduação do Brasil fecha uma década e meia de existência. Das primeiras reuniões para formar a Revista no já distante ano de 2000 (talvez elas já tivessem ocorridos algumas em 1999) aos percalços do final da primeira década do século XXI a Vernáculo se mantém. Não sabemos neste momento o quanto da ideia original formulada por Allan de Paula Oliveira, Fernando Nicollazi, Laís Helena Telles, Mauricio Ouyama, Rafael Faraco Benthien, Rodrigo Turin e Victor Graciotto se mantém. No entanto, podemos afirmar categoricamente que a essência da Revista continua intacta: ser um espaço de divulgação da produção intelectual de discentes de graduação.

Os primeiros números da Vernáculo contavam com um editorial, esta prática, por algum motivo, foi deixada de lado, mas para

\footnotetext{
${ }^{1}$ Graduado em História, UFPR, 2013.

${ }^{2}$ Graduanda em História, UFPR.

${ }^{3}$ Graduado em História e Ciências Sociais UFPR, mestre em História UFRGS, Doutor em História UFPR.
} 
este número mostrou-se necessário retomá-la. Este número que comemora os 15 anos da Revista pede um editorial, entre outros motivos, para prestarmos nosso agradecimento a uma série de pessoas que nos ajudaram nos últimos anos para que pudéssemos colocar em ordem a periodicidade da Vernáculo.

Assim sendo, agradecemos a Natally Nobre, Lukas Gabriel Gryzbowski e ao Leonardo Barleta que foram responsáveis pela digitalização da Revista, sem esta ação colocar a Vernáculo "em dia" seria ainda mais difícil. É de fundamental importância agradecer as pessoas que dispuseram em organizar os dossiês, essenciais, para periodização do periódico: Hector Guerra Hernandez (número 30), Fagner Carniel (número 31), Lennita Oliveira Ruggi (número 32), Karla Gobo (número 33), Ludmila Andrzejewski Culpi (número 33), Márcio Antonio Both (número 34) e Monah Pereira (número 35). E também é importante dizer muito obrigado a Thays Almeida Monticelli e Katiucya Perigo responsáveis por dossiês que ainda serão publicados, mas que já estão preparados.

Gostaríamos também dizer muito obrigado a Ana Paula Bellenzier que vem elaborando as capas da Revista Vernáculo.

A todas e todos que colaboraram e que colaboram para a manutenção deste periódico enviando seus artigos, fazendo pareceres, indicando-o para leitura o nosso muito obrigado! 